WIDER Working Paper 2019/62

Linking Southern Africa into South Africa's global value chains

Karishma Banga ${ }^{1}$ and Neil Balchin ${ }^{2}$

August 2019 
Abstract: This study explores the potential for South Africa to become an engine for intraregional trade and industrial development by linking other Southern African countries to its global value chains and, in the process, improving its global trade competitiveness. The study identifies 'lead products' exported by South Africa, and then uses revealed comparative advantage and unit cost analysis to identify intermediate inputs in which Southern African countries have competitiveness to export that is currently untapped due to a lack of supply capacity or other factors. Such products are potential areas where regional investments could lead to the successful creation of regional value chains. The study also identifies 'new markets' for agricultural lead products exported by South Africa, which could open new opportunities for Southern Africa to supply intermediate agricultural inputs.

Key words: regional integration, regional value chains, Southern Africa, South Africa, global value chains

JEL classification: F10, F15

Acknowledgements: We would like to thank John Page for reviewing the paper and for providing comments and suggestions that have helped to improve it.

\footnotetext{
${ }^{1}$ Senior Research Officer, Overseas Development Institute, London, UK, corresponding author: k.banga@odi.org.uk; ${ }^{2}$ Trade Specialist, Commonwealth Connectivity Agenda, Commonwealth Secretariat, London, UK.

This study has been prepared within the UNU-WIDER project Southern Africa-Towards Inclusive Economic Development (SA-TIED)

Copyright (C) UNU-WIDER 2019

Information and requests: publications@wider.unu.edu

ISSN 1798-7237 ISBN 978-92-9256-696-8

https://doi.org/10.35188/UNU-WIDER/2019/696-8
}

Typescript prepared by Luke Finley.

The United Nations University World Institute for Development Economics Research provides economic analysis and policy advice with the aim of promoting sustainable and equitable development. The Institute began operations in 1985 in Helsinki, Finland, as the first research and training centre of the United Nations University. Today it is a unique blend of think tank, research institute, and UN agency — providing a range of services from policy advice to governments as well as freely available original research.

The Institute is funded through income from an endowment fund with additional contributions to its work programme from Finland, Sweden, and the United Kingdom as well as earmarked contributions for specific projects from a variety of donors.

Katajanokanlaituri 6B, 00160 Helsinki, Finland

The views expressed in this paper are those of the author(s), and do not necessarily reflect the views of the Institute or the United Nations University, nor the programme/project donors. 
Rapid globalization, together with the increasing fragmentation and unbundling of production processes, has resulted in significant changes to the dynamics of global trade. These changes are reflected in a proliferation of internationally joined-up production networks, often spanning multiple countries. Such networks are typically orchestrated by multinational corporations, acting as 'lead firms' and sourcing products from across the world (Viviers and Strydom 2015).

The global unbundling of production has made it possible for countries to specialize in the production of components and parts, rather than having to develop whole industries or sectors. This presents new opportunities for firms in Southern Africa, and elsewhere on the continent, to join transnational value chains, at either the regional or the global level, through backward integration (by sourcing inputs from abroad to produce products for export) or forward integration (by providing inputs for use in the production of another country's exports).

Evidence from theoretical and empirical studies suggests that participation in global or regional value chains (GVCs and RVCs) can generate a range of benefits. Allard et al. (2016) argue that GVC integration is consistently associated with higher levels of productive activity and income growth over time. A study by the OECD (2015) presents evidence that higher levels of backward integration into value chains lead to greater per capita domestic value addition in exports, through access to high-quality and competitively priced imported intermediate products and services which have a positive impact on productivity and competitiveness. The same study also shows that higher levels of backward integration into value chains are associated with the production of moresophisticated exports and greater export diversification over time. Recognising these benefits, Engel (2016) suggests that integration into GVCs can play an important role in helping developing countries to improve their competitiveness and to industrialize.

Within Africa, Southern Africa is the region most integrated into GVCs, accounting for 40 per cent of the continent's overall GVC participation (AfDB et al. 2014; UNECA 2015). Even so, the value added captured by this participation is low, and most Southern African countries remain at the margins of international production networks (AfDB et al. 2014; Farole 2016). High levels of foreign ownership among firms participating in GVCs may be one defining factor, with the control exerted by foreign lead firms preventing suppliers in some cases from moving beyond basic production and into more-sophisticated products with higher levels of value addition. For instance, Banga (2017) analyses the case of Indian manufacturing and finds that captive GVC firms in India produce significantly less-sophisticated goods. The author identifies captive firms as those whose shares of skilled labour and supplier competence fall below the median level in the industry. Such firms are expected to exhibit high lead firm control over the production process. Where Southern African countries are integrated into GVCs, it is generally in the upstream segments of specific value chains, although there is significant heterogeneity across countries and there are some important exceptions - such as Botswana in the diamond value chain or Lesotho's involvement in final-stage apparel assembly (Engel 2016).

In some instances, benefits from integration can be amplified, or are more accessible, through RVCs. Participation in RVCs boosts opportunities for local producers, including small and medium-sized enterprises, to access regional markets (Conde et al. 2015). Integration into RVCs may better support upgrading, since intra-regional markets are often less dominated by a small number of lead firms (Keane 2015a). RVCs are also easier to organize and often have lower administrative burdens (e.g. in terms of rules of origin or requirements related to product 
traceability) (UNECA 2015). In Southern African countries, developing RVCs offers an opportunity to broaden the manufacturing base and expand productive capacity (UNCTAD 2013).

South Africa holds a unique position among countries in the region in terms of its scale of participation in GVCs (UNCTAD 2013). This cuts across a range of sectors, from agriculture and mining to automobiles and finance. As a result, South Africa is well placed-boasting the necessary efficiency and scale of production - to drive the formation of cross-country value chains within Southern Africa.

South Africa already dominates trade within Southern Africa; it is a major source of intermediates for other Southern African countries, and enjoys a sizeable trade surplus in the region (Engel 2016). In the Southern African Customs Union (SACU), for instance, South Africa accounts for 60 per cent of the foreign value added imported into Botswana, Namibia, and Eswatini (known as Swaziland until 2018) (Engel 2016). Across the whole region, South Africa's forward integration into Southern African value chains continues to increase steadily. The value of intermediates imported from South Africa embedded in the exports of other Southern African countries grew five times over from US\$675 million to nearly $\$ 3.5$ billion between 1995 and 2011 (AfDB et al. 2014). Based on 2011 data, as much as 10 per cent of the intermediates imported by Botswana, Namibia, Eswatini, Zambia, and Zimbabwe are sourced from South Africa (AfDB et al. 2014). At the same time, the level of South Africa's backward integration into Southern African value chains has grown significantly since the end of apartheid. According to calculations by the AfDB et al. (2014), there was a nine-fold increase in value in South Africa's use of intermediates imported from other Southern African countries between 1995 and 2011, rising from US\$78 million to \$686 million.

Roughly 97 per cent of all trade in the region involves South Africa (Farole 2016), and the country acts as the de facto 'headquarter' economy in the region (Keane 2015a), playing a leading role in driving the few existing RVCs. It is a large exporter of processed food and consumer goods within the Southern African Development Community (SADC) region, and dominates supermarkets throughout Southern Africa (das Nair and Chisoro-Dube 2016). In the textile and apparel industries, strong (albeit short) RVCs have also been developing in recent years, with increasing pressure on producers based in South Africa to lower production costs combined with the growing scale of the regional retail market (Farole 2016). Although no co-ordinated regional poultry value chains exist in Southern Africa (Ncube et al. 2017), existing poultry production in the region has been led by large vertically integrated firms, predominantly from South Africa (Bagopi et al. 2014). South Africa is also a major non-oil investor in the region, and commercial enterprises are a key driver of the country's regional engagement (Games 2017).

Looking ahead, Farole (2016) focuses on the SACU region and argues that there is potential to develop a 'Factory Southern Africa' model, built around South Africa as a manufacturing hub, to replicate the successful Factory Asia manufacturing model in South East Asia. He contends that South Africa boasts capabilities on par with a number of South East Asian nations on a range of factors central to production competitiveness, including logistics capabilities, the strength of institutions, and human and financial capital. Moreover, he argues, there exist strong complementarities in the capabilities of South Africa and other SACU countries (Botswana, Lesotho, Namibia, and Eswatini) that are amenable to a hub-and-spoke type of model in which RVCs (led by South Africa) link into GVCs.

In this context, the main objective of this study is to identify South Africa's 'lead products', for which it has formed its own GVCs, and, based on those highlighted, to identify intermediate products that can enable other Southern African countries to link into South Africa's GVCs by 
supplying inputs more competitively than existing sources. The study also estimates the potential market share that other Southern African countries can capture in South Africa's market.

The primary data source is export-import data from the World Integrated Trade Systems (WITS) data set from UN Comtrade. ${ }^{1}$ Inputs that are currently being sourced domestically (i.e. from within South Africa) have not been included in the analysis, in order to leave the existing domestic supply chains intact. Only those inputs that are currently being imported as inputs into the production of South Africa's lead products are examined, and Southern African countries that can link into South Africa's GVCs by supplying these inputs are identified. In doing this, we also consider potential policy interventions to support other Southern African countries to integrate successfully into these value chains.

The objectives of the study are two-fold:

1. First, it identifies the existing lead products of South Africa, in which South Africa forms its own GVCs, and estimates the potential market share that Southern African countries could capture in South Africa's markets by supplying intermediate inputs for these lead products. This provides a basis for selecting products for potential investment to increase regional integration in Southern Africa.

2. Secondly, narrowing the analysis to the agricultural sector-a key regional priority sector with immense potential for industrial growth and large-scale employment-the study identifies existing agricultural lead products in South Africa, and the 'new markets' to which South Africa can export. This is intended to highlight products in which South Africa can expand its existing GVCs to new markets and potentially increase regional integration.

Section 2 presents the dynamics of value chain integration in Southern Africa across broad sectors. Following this, Section 3 provides a description of the policy environment supporting regional trade and value chains in Southern Africa. Section 4 presents the data and methodology used in the study to identify potential RVCs and new markets for South Africa. Section 5 presents and discusses the results. Finally, Section 6 concludes and suggests policy interventions to support further integration around RVCs in Southern Africa.

\section{The dynamics of integration in Southern Africa}

Most Southern African countries are trading at levels above those which would be predicted from their income levels alone (Engel 2016). However, much of this is biased towards commodity exports and consumption imports, especially among the SACU countries, where the shares of intermediates in exports and imports are lower for the region as a whole compared with a selection of peer countries (Engel 2016).

The nature of Southern Africa's integration into international value chains to date suggests that there is ample room for improvement. The further development of intra-regional trade and RVCs can be a useful starting point. Existing levels of intra-regional trade in Southern Africa are low and have not increased substantially. For instance, previous estimates have suggested that roughly 90 per cent of total SADC trade remains with countries outside the region (Tralac 2017). This is

\footnotetext{
${ }^{1}$ https:// comtrade.un.org.
} 
markedly lower, for instance, than the level of intra-regional trade among South East Asian nations (24 per cent) (Tralac 2017).

\subsection{Which sectors exhibit higher regional integration?}

Outside of the apparel sector, which involves a short value chain centred around cut-make-trim operations and mostly relies on inputs imported from outside the region, RVCs in Southern Africa remain underdeveloped and are largely limited to consumer-oriented products (e.g. cocoa, dairy products, detergents, plastics, soap) rather than industrial goods (Farole 2016; Keane 2015a).

Where value chains have emerged that span multiple Southern African countries, they tend to be dominated by South Africa. Some integration within the region has been structured through supermarket supply chains-led by South African supermarkets-which has helped to drive regional trade in processed foods and household consumables. But this trade is generally heavily skewed in favour of South Africa (from which many of the products are imported for sale in other Southern African countries) and a range of barriers, particularly those related to requirements and standards, constrain the participation of local firms looking to supply the large supermarket chains (das Nair and Chisoro-Dube 2016).

In the clothing sector, multi-country production in the region has again been led predominantly by South Africa. From 2006 onwards, in the face of challenges in the domestic industry, South African apparel manufacturers opted to relocate some or all of their operations to Lesotho and Eswatini in order to benefit from lower labour costs and duty-free access to the South African market through SACU (Balchin and Calabrese 2019; Godfrey 2015). This gave rise to triangular manufacturing arrangements in which orders were received from South African retailers, designs and fabrics were sent to Lesotho or Eswatini for garment assembly, and the final products were exported back to retailers in South Africa (Godfrey 2015). The result has been a delocalization within the value chain, driven by South African retailers.

Outside of these sectors, some studies note the existence of a type of production network in metals within the region. Some metal products are exported by South Africa to other SACU members, which re-export them back to South Africa (Keane 2015b). However, these products do not feature within South Africa's major extra-regional exports. In some Southern African countries, such as Botswana and Namibia, the metal sector also ranks high in terms of growth in total foreign value added (Farole 2016).

South Africa is also dominant in other sectors, such as agro-processing. Although there are few examples of integrated regional agro-processing supply chains, there are some chains in which processors have established facilities across the region to capitalize on the respective countries' competitive advantages and produce for export markets (Grobbelaar and Meyer 2017).

Despite progress in these sectors, challenges remain to further value chain integration in Southern Africa. Principal among these is the considerable asymmetry in size and productive capacity between South Africa and the other countries in the region (Farole 2016). This makes it difficult for other Southern African countries to supply inputs to South Africa competitively and in accordance with the required volumes and standards. In addition, although progress has been made in liberalizing intra-regional trade (discussed below), there remain significant trade barriers in the region. These include a range of non-tariff barriers; the persistence of infant industry protection, quotas and bans, and licensing requirements; and a lack of harmonization of standards and labelling (Farole 2016).

\subsection{The policy environment for regional integration and value chains in Southern Africa}


Good progress has already been made in liberalizing intra-regional trade in Southern Africa. The SADC Protocol on Trade paved the way for a staged tariff reform process-starting from 1 January 2000-following an agreed annual tariff phase-down schedule that allowed for product and country differentiation in the level and pace of liberalization (Balchin et al. 2016a). ${ }^{2}$ In recognition of the different levels of development across SADC countries, there was significant heterogeneity in the rates at which participating SADC Member States committed to reducing their tariff lines on certain products (Balchin et al. 2016a).

Similarly, the SACU trade regime has undergone notable liberalization in recent decades, especially over the period from 1990 to 2006. Discussions are ongoing to further liberalize trade and boost regional integration, including through wider trade agreements that span multiple regions in Africa, such as the Tripartite Free Trade Area and the African Continental Free Trade Area (AfCFTA).

Aside from the overarching agreements for liberalizing intra-regional trade, there is ongoing policy prioritization for deepening regional integration, including through a range of regional frameworks to support integration, facilitate linkages between economies, and support efforts to produce higher value-added goods in SADC. For instance, the SADC Industrial Upgrading and Modernization Programme (adopted in 2009) aims to reinforce institutional support for improving productivity and competitiveness in order to enhance beneficiation and value addition (UNECA 2017). This is focused around nine priority sectors: agro-food processing, fisheries, wood and wood products, textiles and garments, leather and leather products, beneficiation of mineral products, pharmaceuticals and chemicals, machinery and equipment, and services.

SADC's Revised Regional Indicative Strategic Development Plan (RISDP) 2015-2020 (SADC 2015a) seeks to advance economic diversification within the region through the promotion of industrial linkages between countries and increased value addition. The plan places industrialization at the forefront of SADC's integration agenda. Linked to this, the SADC Industrial Development Policy Framework (SADC 2014) was devised to implement the RISDP. Its overarching goal is to develop an integrated industrial base in Southern Africa by exploiting regional synergies in value-added production and enhancing export competitiveness (UNECA 2017).

Much of this is given practical expression through the $S A D C$ Industrialization Strategy and Roadmap 2015-2063 (SADC 2015b), which outlines a long-term action plan to link the SADC industrialization push to the African Union's Agenda 2063. The Roadmap prioritizes regional integration and industrialization. This is to be achieved in three phases, with the first - running from 2015 to 2020 - looking to front-load industrial development and market integration. This phase includes emphasis on the provision of related infrastructure and services to support industrialization. The second phase, running from 2021 through to 2050, focuses on diversifying SADC economies and enhancing productivity and competitiveness. Finally, the third stage (205163) targets innovation through the adoption of advanced technologies and improvements in business sophistication. The importance of integrating SADC economies into RVCs and GVCs to spur industrialization is emphasized across all three phrases.

In addition to these SADC-wide policy frameworks, the SACU countries are also in the process of devising a regional industrial development policy for the customs union. Importantly, this

\footnotetext{
${ }^{2}$ Certain products that already attracted low or zero tariffs were placed in Category A and earmarked for immediate liberalization, whereas Category B products, identified as important sources of customs revenue, were to be liberalized gradually over an eight-year period. A further group of products (Category C), deemed to be of critical economic importance to SADC Member States, were to be eliminated between 2008 and 2012. The latter grouping was limited to a maximum of 15 per cent of each Member State's intra-SADC merchandise trade (Kalenga 2009).
} 
process has identified the agro-processing and automotive sectors as priorities for cross-country collaboration. Regional co-operation in these sectors is regarded as offering significant potential for Botswana, Lesotho, Namibia, and Eswatini to access larger GVCs.

These multi-country policy frameworks are complemented by individual national industrial policies, many of which focus on beneficiation and value addition. Among these, South Africa's industrial policy includes emphasis on regional dimensions. Specifically, the country's industrial policymakers regard integration into RVCs as a means to promote both South Africa's and the region's economic development.

More generally, the broader continental integration efforts in motion can help to drive the development of RVCs in Southern Africa and beyond. The first phase of negotiations towards the AfCFTA focused on trade in goods; trade in services; and rules and procedures in the settlement of disputes. The second phase, currently underway, covers investment, intellectual property rights, and competition policy. The economic integration envisaged under the AfCFTA process are intended to provide the tariff liberalization, trade facilitation, and trade policy coherence necessary to support the development of RVCs in Southern Africa and elsewhere on the continent.

Even with the extensive array of policy frameworks promoting regional integration and the forward-looking continental integration initiatives, more could be done at the regional level to support value chain development. The nature and scope of non-tariff barriers (NTBs) in Southern Africa is very complex and includes, among other things, weak transport and logistics; customs delays; restrictive rules of origin; import bans, quotas, and levies; technical barriers; import permits and licensing; and export restrictions. The World Bank's Logistics Performance Index (World Bank 2018) shows that, barring South Africa and Botswana, Southern African countries perform relatively poorly on logistics. Substantial efforts are required, especially in areas such as customs and border procedures, transport infrastructure, and the availability and quality of logistics services.

There has also been limited progress to date in generating agreement at the regional level on key factors to facilitate RVCs, including in relation to services trade and the movement of natural persons, intellectual property rights, and corresponding investment agreements. For instance, using the Services Trade Restrictiveness Index (STRI), ECA-SA (2018) finds that while the SADC average STRI is not too far from the world average in most services sectors, in telecommunications it is twice as restrictive as the world average. In some services sectors, such as retail, banking, and insurance, licence fees remain prohibitively high, while in professional services, domestic regulations on entry remain a key impediment to regional trade. There are major skills shortages in engineering and IT services as well as accounting and legal services across Southern African countries.

The global trading environment is currently undergoing rapid transformation as a result of the adoption of digital technologies such as big data, cloud computing, and robotics. Appropriate and forward-looking policies need to be developed to leverage these digital technologies for boosting regional integration. On the production side, these technologies can generate productivity and product sophistication gains (Banga and te Velde 2018a), creating new opportunities for firms to further integrate into the global and regional economy. For example, Banga and te Velde (2018b) put forward the case of Funkidz, a children's furniture manufacturing enterprise in Kenya that has invested heavily in digital machinery. Adopting digital technologies in production has allowed this firm to produce mass quantities of good-quality furniture to exact specifications, and as a result the firm has expanded into the regional markets of Uganda and Rwanda. On the transaction side, the use of big data, digital payments, e-commerce, and digital customs holds immense potential to boost regional trade and integration through the creation of efficiencies in logistics and delivery, and through reductions in transaction costs and trade barriers. Regional harmonization of 
intellectual property, and monitoring/tracking of patent and trademarks through digital databases, can also facilitate greater regional integration (Banga and te Velde 2018b).

SADC has put in place a Digital 2027 agenda, aimed at consolidating regional telecommunications networks, transport and postal infrastructures, e-services development, and ICT infrastructure development (SADC 2012). The Common Market for Eastern and Southern Africa also has plans underway for the implementation of a Digital Free Trade Area (DFTA) - an online platform for trade facilitation through electronic trade, e-logistics, and e-legislation (Hope 2018).

To effectively leverage the digital economy to boost regional integration, UNCTAD (2018) proposes a ten-point agenda for South-South digital co-operation. While the sequencing and prioritizing of the policies will depend on country-specific characteristics such as the level and pace of digital development, the agenda calls for regional blocs to (i) build a data economy; (ii) develop cloud computing infrastructure; (iii) strengthen broadband infrastructure; (iv) promote ecommerce in the region; (v) promote digital payments; (vi) ensure progress on a single digital market in the region; (vii) share experiences on e-government; (viii) forge partnerships for building smart cities; (ix) promote digital innovations and technologies; and (x) build statistics for measuring digital progress (UNCTAD 2018). The report further acknowledges the role of large countries within a region — such as South Africa in the case of Southern Africa-as a driver of regional digital growth.

\section{Data and methodology}

To identify potential products through which Southern African countries can link into South Africa's GVCs, this study draws closely on the methodology developed by Commonwealth Secretariat (2016) for linking least-developed countries into India's GVCs. For a product to form its own GVC, it is important that it is a finished product and ready to be consumed by consumers, or is a capital good to be consumed by industry. Such products provide an opportunity for South Africa to form its own competitive GVCs, and for Southern African countries to link into these value chains.

\subsection{Identifying South Africa's lead products}

In the first step, product-level export data is collected for South Africa from the WITS database at the Harmonized System (HS) six-digit level (2012 classification) for the years 2015-17. The analysis is based on average trade flows over three years to avoid any year-to-year fluctuations.

The finished products are identified on the basis of the United Nations' Broad Economic Categories (BEC), as capital goods for industry consumption or household consumption goods. A concordance is undertaken at the six-digit level of HS 2012 with the BEC classification to identify intermediate and final exports by South Africa. The study then selects the top ten finished consumer and capital products (lead products) being exported by South Africa.

\subsection{Identifying imported intermediate inputs in the lead products}

Using concordance matrices, the study matches each of the ten lead products (at HS six-digit level) identified through the approach outlined in Section 3.1 with the BEC classification category to identify the intermediate inputs used in their production. For example, for the lead product HS 870421 (vehicles, for transport of goods), intermediate inputs are those classified under the BEC 
category 53 (transport equipment for industry). Identification of intermediate inputs is further validated through input-output tables.

From within these intermediate products, the study identifies those inputs that South Africa is currently importing from other countries but that could be sourced more cost-competitively from Southern African countries. Only those inputs that South Africa is already importing are considered-hence the analysis in this study does not impact the existing domestic supply chains in South Africa. The average import value (over the period 2015-17) is calculated for each intermediate product imported by South Africa, and the top 20 imported intermediate inputs are selected for analysis. These inputs are classified under the following BEC intermediate input categories: 53 (parts and accessories of transport equipment); 42 (parts and accessories of capital goods); 121 (processed foods and beverages, mainly for industry); and 111 (primary foods and beverages, mainly for industry).

\subsection{Comparing the competitiveness of Southern African countries in the identified intermediate inputs}

The concept of comparative advantage is rooted in conventional trade theory and is widely deployed in modern economic literature to evaluate the trade and specialization patterns of countries. There are different methods available to measure comparative advantages of countries across products; this study uses the revealed comparative advantage (RCA) index introduced by Balassa (1965) — the most commonly used indicator in empirical work.

For each of the top 20 identified intermediate products, the study calculates the bilateral RCA for each country exporting to South Africa. It then identifies which Southern African countries have a higher RCA in a particular intermediate input compared with the main markets from which South Africa is currently importing the product.

The bilateral RCA for country $i$ in product $k$ is calculated as:

$$
R C A_{i k}=\frac{X_{i k \text { South Africa }}}{X_{\text {ikWorld }}} / \frac{X_{\text {iSouth Africa }}}{X_{\text {iWorld }}}
$$

where $X_{i k S o u t h}$ Africa refers to exports of country $i$ in product $k$ to South Africa, $X_{i k W o r l d}$ refers to exports of country $i$ in product $k$ to the world, and $X_{\text {isouth Africa }}$ and $X_{i W o r l d}$ refer to total exports of country $i$ to South Africa and to the world respectively. Exports are averaged over 2015-17 to deal with yearly fluctuations. A ratio greater than 1 implies that the country is competitive in the product; the higher the RCA in a particular product, the higher the country's competitiveness in that product.

Some studies have criticized Balassa's RCA index for having poor empirical distribution characteristics (De Benedictis and Tamberi 2004) and for taking only exports into consideration while ignoring imports (Cai and Leung 2008). Since export unit values do not capture additional costs such as freight or transport costs, the study complements RCA analysis by comparing import unit values for South Africa importing these products from different countries. By doing this, the study is able to identify Southern African countries that not only are more competitive in a particular product but also export the product to South Africa at a lower unit cost (which represents another dimension of overall competitiveness). Import unit value is calculated as export unit value (export value/export volume) for each country in each of the 20 products exported to South Africa plus the cost, insurance, and freight (CIF) charges borne by South Africa when it 
imports. These CIF-FOB (free on board) margins are taken at the four-digit level from the International Transport and Insurance Costs of Merchandise Trade (ITIC) data set. ${ }^{3}$

\subsection{Estimating additional potential market access for Southern African countries in South Africa's market}

The scope for additional market share of a Southern African country in South Africa's market for a particular intermediate input is calculated as the sum of the exports of its competitor countries that not only have a lower comparative advantage in the product (lower bilateral RCA than the Southern African country) but also have a higher import unit value in South Africa's market. This calculation helps to identify countries within the Southern African region that have the potential to supply these inputs more cost-effectively than do current suppliers. If it is determined that the Southern African countries are currently unable to supply the inputs to South Africa due to a lack of capacity, then those inputs will be identified as potential products for regional investments.

\subsection{Finding new markets for South Africa's lead products}

The above methodology will help to identify products for which there is potential to form or strengthen RVCs. In this final step, we narrow down the analysis to focus on the agricultural sector-a priority sector for regional integration in Southern African-and identify new markets for South Africa's agricultural lead products (finished agricultural products for household consumption). To identify these new markets, the study follows the methodology developed in the Commonwealth Secretariat's (2017) study on export diversification in Jamaica.

We first identify South Africa's top agricultural lead products currently being exported, using data averaged over the period 2015-17. To identify new markets for South Africa, the study (i) identifies the top ten global importers of the product (by value); (ii) identifies which importers, within the top ten, are not importing from South Africa; and (iii) compares South Africa's competitiveness with that of existing exporters to these markets using global RCA.

The global RCA for country $i$ in product $k$ is calculated as:

$$
R C A_{i k}=\frac{X_{i k}}{X_{\text {worldk }}} / \frac{X_{i}}{X_{\text {World }}}
$$

where, $X_{i k}$ refers to exports of country $i$ in product $k$ to the world, $X_{W o r l d k}$ refers to exports of the world in product $k$, and $X_{i}$ and $X_{\text {World }}$ refer to total exports of country $i$ and the world respectively. Exports are averaged over 2015-17. A ratio greater than 1 implies that the country is competitive in the product; the higher the RCA in a particular product, the higher the country's global competitiveness in that product.

4 Identifying products for potential regional value chains in Southern Africa and new markets for South Africa

\subsection{Potential regional value chains for Southern African countries}

\footnotetext{
${ }^{3}$ https://stats.oecd.org/Index.aspx?DataSetCode=CIF_FOB_ITIC\#.
} 
As described above, the study identifies lead products as final consumer goods or capital goods for consumption using the BEC classification. Using this definition, South Africa's top exported lead products are (broadly) identified in Table 1 as vehicles for the transport of goods; machinery for filtering gases; wine; medicaments; cosmetic preparations; food preparations; containers; telephones; and cigarettes.

Table 1: Top ten lead products exported by South Africa (average 2015-17)

\begin{tabular}{|c|c|c|}
\hline $\begin{array}{l}\text { Product code } \\
\text { (HS 2012) }\end{array}$ & Description of the lead product & $\begin{array}{l}\text { Exports (in } \\
\text { million US\$) }\end{array}$ \\
\hline 870421 & Vehicles, for transport of goods & 2,333 \\
\hline 842139 & Machinery; for filtering or purifying gases & 1,497 \\
\hline 220421 & Wine; still, in containers holding 2 litres or less & 465 \\
\hline 300490 & $\begin{array}{l}\text { Medicaments; consisting of mixed or unmixed products, for therapeutic or } \\
\text { prophylactic uses, packaged for retail sale }\end{array}$ & 265 \\
\hline 330499 & Cosmetic and toilet preparations; for the care of the skin & 214 \\
\hline 220429 & Wine; still, in containers holding more than 2 litres & 202 \\
\hline 210690 & Food preparations; n.e.s. in item no. 2106.10 & 176 \\
\hline 860900 & $\begin{array}{l}\text { Containers; (including containers for transport of fluids) specially designed } \\
\text { and equipped for carriage by one or more modes of transport }\end{array}$ & 166 \\
\hline 851712 & Telephones for cellular networks or for other wireless networks & 155 \\
\hline 240220 & Cigarettes; containing tobacco & 140 \\
\hline
\end{tabular}

Note: Exports are averaged over 2015-17; n.e.s. = not elsewhere specified.

Source: Authors' construction based on UN Comtrade (BEC data).

In order to identify which Southern African countries can link into South Africa's existing exports of the lead products, we trace the existing value chains for the identified lead products and identify the top 20 imported inputs. For each of the 20 imported inputs, we calculate the bilateral RCA of countries in South Africa's market and estimate the import unit value at which South Africa is importing these products from other countries.

Table 2 identifies Zambia, Botswana, Mozambique, Namibia, and Zimbabwe as cost-competitive sources of inputs for South Africa compared with the existing sources of those inputs. Overall, potential intermediate products that Southern Africa can provide in South Africa's GVCs include parts and accessories of vehicles, printing machinery, telephone sets, machinery for handling ores and earth, reception and transmission apparatus, data and digital processing automatic units, and wiring sets; and pneumatic rubber tyres. The table lists potential product-country pairs of the Southern African partners identified, along with their potential market access in South Africa.

Table 2: Identifying potential regional value chains in Southern Africa

\begin{tabular}{|c|c|c|c|c|c|c|c|}
\hline HS six-digit input & $\begin{array}{l}\text { Intermediate } \\
\text { Input }\end{array}$ & $\begin{array}{l}\text { Final product } \\
\text { being } \\
\text { exported by } \\
\text { South Africa }\end{array}$ & $\begin{array}{l}\text { Less- } \\
\text { competitive } \\
\text { countries SA } \\
\text { is currently } \\
\text { importing } \\
\text { inputs from } \\
\text { (examples) }\end{array}$ & $\begin{array}{l}\text { Southern } \\
\text { African } \\
\text { countries with } \\
\text { potential to } \\
\text { export }\end{array}$ & $\begin{array}{r}\text { Potential } \\
\text { Exports } \\
(1,000 \\
\text { US\$) }\end{array}$ & $\begin{array}{r}\text { Current } \\
\text { exports } \\
\text { to SA } \\
(1,000 \\
\text { US } \$)\end{array}$ & $\begin{array}{r}\text { Current } \\
\text { exports } \\
\text { to the } \\
\text { world } \\
(1,000 \\
\text { US\$) }\end{array}$ \\
\hline
\end{tabular}




\begin{tabular}{|c|c|c|c|c|c|c|c|}
\hline \multirow[t]{4}{*}{844399} & \multirow{4}{*}{$\begin{array}{l}\text { Printing } \\
\text { machinery; } \\
\text { parts and } \\
\text { accessories }\end{array}$} & \multirow{4}{*}{$\begin{array}{l}\text { Medicaments } \\
\text { for retail }\end{array}$} & \multirow{4}{*}{$\begin{array}{l}\text { Lithuania, } \\
\text { Ireland, } \\
\text { Malaysia, } \\
\text { Thailand, } \\
\text { Lithuania, } \\
\text { Ireland, } \\
\text { Japan, China }\end{array}$} & Zambia & 35 & 15 & 17 \\
\hline & & & & Botswana & 163,828 & 22 & 23 \\
\hline & & & & Mozambique & 35 & 41 & 41 \\
\hline & & & & Namibia & 151,691 & 10.5 & 18 \\
\hline \multirow[t]{4}{*}{843149} & \multirow{4}{*}{$\begin{array}{l}\text { Machinery; } \\
\text { parts of } \\
\text { machines } \\
\text { handling } \\
\text { earth, ores }\end{array}$} & \multirow{4}{*}{$\begin{array}{l}\text { Vehicles for } \\
\text { transport of } \\
\text { goods }\end{array}$} & \multirow{4}{*}{$\begin{array}{l}\text { France, } \\
\text { Sweden, } \\
\text { Belgium, } \\
\text { Sweden, } \\
\text { Cameroon, } \\
\text { Germany, } \\
\text { Bulgaria, } \\
\text { Saudi Arabia }\end{array}$} & Zambia & 48,656 & 6,896 & 9,916 \\
\hline & & & & Botswana & 86,559 & 5,562 & 7,173 \\
\hline & & & & Namibia & 34,375 & 1,529 & 3,248 \\
\hline & & & & Mozambique & 1,785 & 378 & 1,283 \\
\hline \multirow[t]{2}{*}{851770} & \multirow[b]{2}{*}{$\begin{array}{l}\text { Telephone } \\
\text { sets and } \\
\text { other } \\
\text { apparatus; } \\
\text { transmission, } \\
\text { reception; } \\
\text { parts }\end{array}$} & \multirow{2}{*}{$\begin{array}{l}\text { Telephones } \\
\text { for cellular } \\
\text { networks or } \\
\text { for other } \\
\text { wireless } \\
\text { networks }\end{array}$} & \multirow{2}{*}{$\begin{array}{l}\text { New } \\
\text { Zealand, } \\
\text { Denmark, } \\
\text { Malaysia, } \\
\text { Germany, } \\
\text { Denmark }\end{array}$} & Zambia & 6,770 & 9 & 49 \\
\hline & & & & Namibia & 66,648 & 12 & 18 \\
\hline \multirow[t]{3}{*}{870829} & \multirow{3}{*}{$\begin{array}{l}\text { Vehicles; } \\
\text { parts and } \\
\text { accessories, } \\
\text { of bodies, } \\
\text { other than } \\
\text { seat belts }\end{array}$} & \multirow{3}{*}{$\begin{array}{l}\text { Vehicles for } \\
\text { transport of } \\
\text { goods }\end{array}$} & \multirow{3}{*}{$\begin{array}{l}\text { Brazil, } \\
\text { Thailand, } \\
\text { Germany, } \\
\text { Hungary, } \\
\text { Indonesia, } \\
\text { Belgium, } \\
\text { Netherlands, } \\
\text { Morocco }\end{array}$} & Zambia & 627,631 & 48 & 77 \\
\hline & & & & Botswana & 12,656 & 105 & 319 \\
\hline & & & & Namibia & 22 & 9 & 24 \\
\hline \multirow[t]{3}{*}{852990} & \multirow{3}{*}{$\begin{array}{l}\text { Reception } \\
\text { and } \\
\text { transmission } \\
\text { apparatus }\end{array}$} & \multirow{3}{*}{$\begin{array}{l}\text { Telephones } \\
\text { for cellular } \\
\text { networks or } \\
\text { for other } \\
\text { wireless } \\
\text { networks }\end{array}$} & \multirow{3}{*}{$\begin{array}{l}\text { Malaysia, } \\
\text { Indonesia, } \\
\text { Spain, } \\
\text { Singapore, } \\
\text { Denmark, } \\
\text { Belgium, } \\
\text { Benin, } \\
\text { Malaysia, } \\
\text { China }\end{array}$} & Zambia & 66,990 & 4 & 7.5 \\
\hline & & & & Botswana & 27,329 & 14 & 36 \\
\hline & & & & Namibia & 38,070 & 29.5 & 46 \\
\hline \multirow[t]{4}{*}{870899} & \multirow{4}{*}{$\begin{array}{l}\text { Vehicles; } \\
\text { parts and } \\
\text { accessories, }\end{array}$} & \multirow{4}{*}{$\begin{array}{l}\text { Vehicles for } \\
\text { transport of } \\
\text { goods }\end{array}$} & \multirow{4}{*}{$\begin{array}{l}\text { Poland, } \\
\text { Norway, } \\
\text { USA, Chile, } \\
\text { Poland, } \\
\text { Norway, } \\
\text { Senegal, } \\
\text { Peru, Finland }\end{array}$} & Zambia & 78,031 & 483 & 1,627 \\
\hline & & & & Botswana & 83,646 & 919 & 2,297 \\
\hline & & & & Zimbabwe & 504 & 351 & 373 \\
\hline & & & & & & & \\
\hline \multirow[t]{5}{*}{848180} & \multirow{5}{*}{$\begin{array}{l}\text { Taps, cocks, } \\
\text { valves, and } \\
\text { similar } \\
\text { appliances; } \\
\text { for pipes, } \\
\text { boiler, or the } \\
\text { like }\end{array}$} & \multirow{5}{*}{$\begin{array}{l}\text { Machinery for } \\
\text { filtering or } \\
\text { purifying } \\
\text { gases }\end{array}$} & \multirow{5}{*}{$\begin{array}{l}\text { Germany, } \\
\text { Sweden, } \\
\text { France }\end{array}$} & Zambia & 208,069 & 466 & 604 \\
\hline & & & & Botswana & 197,365 & 220 & 273 \\
\hline & & & & Mozambique & 110,367 & 88 & 113 \\
\hline & & & & Namibia & 186,799 & 24.5 & 52 \\
\hline & & & & Zimbabwe & 87,845 & 26 & 29 \\
\hline \multirow[t]{3}{*}{880330} & \multirow{3}{*}{$\begin{array}{l}\text { Aircraft and } \\
\text { spacecraft; } \\
\text { parts of } \\
\text { aeroplanes/ } \\
\text { helicopters }\end{array}$} & \multirow{2}{*}{$\begin{array}{l}\text { Vehicles for } \\
\text { transport of } \\
\text { goods }\end{array}$} & Belgium, & Zambia & 81,599 & 619 & 3,293 \\
\hline & & & $\begin{array}{l}\text { Denmark, } \\
\text { Madagascar, } \\
\text { Tanzania }\end{array}$ & Botswana & 5,295 & 202 & 1,023 \\
\hline & & $\begin{array}{l}\text { Containers } \\
\text { for carriage }\end{array}$ & & & & & \\
\hline
\end{tabular}




\begin{tabular}{|c|c|c|c|c|c|c|c|}
\hline \multirow[t]{2}{*}{401120} & \multirow[b]{2}{*}{$\begin{array}{l}\text { New } \\
\text { pneumatic } \\
\text { rubber tyres, } \\
\text { used on } \\
\text { buses or } \\
\text { lorries }\end{array}$} & \multirow{2}{*}{$\begin{array}{l}\text { Containers } \\
\text { for carriage }\end{array}$} & \multirow{2}{*}{$\begin{array}{l}\text { Indonesia, } \\
\text { Netherland }\end{array}$} & Namibia & 312,465 & 125 & 302 \\
\hline & & & & Zimbabwe & 311,602 & 761 & 863 \\
\hline \multirow[t]{4}{*}{847330} & \multirow{4}{*}{$\begin{array}{l}\text { Machines; } \\
\text { parts and } \\
\text { accessories } \\
\text { of automatic } \\
\text { data and } \\
\text { digital } \\
\text { processing } \\
\text { units }\end{array}$} & \multirow{4}{*}{$\begin{array}{l}\text { Telephones } \\
\text { for cellular } \\
\text { networks or } \\
\text { for other } \\
\text { wireless } \\
\text { networks }\end{array}$} & \multirow{4}{*}{$\begin{array}{l}\text { UK, } \\
\text { Denmark, } \\
\text { France, } \\
\text { Norway }\end{array}$} & Mozambique & 95,494 & 24 & 30 \\
\hline & & & & Namibia & 95,485 & 34 & 61 \\
\hline & & & & Botswana & 87,792 & 147 & 828 \\
\hline & & & & Zimbabwe & 36,738 & 162 & 213 \\
\hline 401110 & $\begin{array}{l}\text { New } \\
\text { pneumatic } \\
\text { tyres, of } \\
\text { rubber, used } \\
\text { on motor cars }\end{array}$ & $\begin{array}{l}\text { Vehicles for } \\
\text { transport of } \\
\text { goods }\end{array}$ & $\begin{array}{l}\text { Japan, } \\
\text { China, } \\
\text { Germany, } \\
\text { Korea }\end{array}$ & Botswana & 188,567 & 85.5 & 181 \\
\hline 870830 & $\begin{array}{l}\text { Parts and } \\
\text { accessories } \\
\text { of motor } \\
\text { vehicles, } \\
\text { brakes and } \\
\text { servo-brakes; } \\
\text { parts thereof }\end{array}$ & $\begin{array}{l}\text { Vehicles for } \\
\text { transport of } \\
\text { goods }\end{array}$ & $\begin{array}{l}\text { Peru, } \\
\text { Finland, } \\
\text { Austria }\end{array}$ & Zambia & 20 & 162 & 190 \\
\hline 854430 & $\begin{array}{l}\text { Ignition wiring } \\
\text { sets and } \\
\text { other wiring } \\
\text { sets used in } \\
\text { vehicles, } \\
\text { aircraft, or } \\
\text { ships }\end{array}$ & $\begin{array}{l}\text { Vehicles for } \\
\text { transport of } \\
\text { goods } \\
\text { Containers } \\
\text { for carriage }\end{array}$ & $\begin{array}{l}\text { USA, France, } \\
\text { UK }\end{array}$ & Botswana & 22,953 & 50 & 327 \\
\hline \multirow[t]{4}{*}{853710} & \multirow{4}{*}{$\begin{array}{l}\text { Boards, } \\
\text { panels, etc. } \\
\text { for electric } \\
\text { control/ } \\
\text { distribution of } \\
\text { electricity }\end{array}$} & \multirow{3}{*}{$\begin{array}{l}\text { Telephones } \\
\text { for cellular } \\
\text { networks or } \\
\text { for other } \\
\text { wireless } \\
\text { networks }\end{array}$} & \multirow{4}{*}{$\begin{array}{l}\text { Germany, } \\
\text { China, USA, } \\
\text { Malaysia, } \\
\text { China, } \\
\text { Thailand, } \\
\text { France }\end{array}$} & Zambia & 293,051 & 65 & 103 \\
\hline & & & & Botswana & 94,473 & 53 & 277 \\
\hline & & & & Mozambique & 3.5 & 28.5 & 76.5 \\
\hline & & $\begin{array}{l}\text { Machinery; } \\
\text { for filtering or } \\
\text { purifying } \\
\text { gases }\end{array}$ & & & & & \\
\hline \multirow[t]{5}{*}{840999} & \multirow{5}{*}{$\begin{array}{l}\text { Engines; } \\
\text { parts for } \\
\text { internal } \\
\text { combustion } \\
\text { piston } \\
\text { engines }\end{array}$} & \multirow{5}{*}{$\begin{array}{l}\text { Vehicles for } \\
\text { transport of } \\
\text { goods }\end{array}$} & \multirow{5}{*}{$\begin{array}{l}\text { USA, } \\
\text { Netherlands, } \\
\text { Thailand, } \\
\text { Belgium, } \\
\text { India, Japan }\end{array}$} & Zambia & 159,205 & 155 & 283 \\
\hline & & & & Botswana & 124,506 & 158.5 & 301 \\
\hline & & & & Mozambique & 83,961 & 44 & 104.5 \\
\hline & & & & Namibia & 111,128 & 97 & 208 \\
\hline & & & & Zimbabwe & 9,331 & 214 & 220 \\
\hline \multirow[t]{2}{*}{842199} & \multirow[b]{2}{*}{$\begin{array}{l}\text { Machinery; } \\
\text { centrifuges, } \\
\text { parts for } \\
\text { filtering or } \\
\text { purifying } \\
\text { liquids or } \\
\text { gases }\end{array}$} & \multirow{2}{*}{$\begin{array}{l}\text { Machinery for } \\
\text { filtering or } \\
\text { purifying } \\
\text { gases }\end{array}$} & \multirow{2}{*}{$\begin{array}{l}\text { Germany, } \\
\text { Japan, } \\
\text { Thailand, } \\
\text { Sweden, } \\
\text { Norway }\end{array}$} & Botswana & $107,273.5$ & 7.6 & 9.6 \\
\hline & & & & Zambia & 2,469 & 33 & 170 \\
\hline
\end{tabular}

Notes: Some Southern African countries such as Malawi are excluded from the unit cost analysis because CIF margins are not available for them in the ITIC database. Potential exports in some cases may denote an estimate 
of the lower interval for the same reason. Examples of less-competitive countries included above are in most cases those countries that have the highest value of exports to South Africa.

Source: Authors' construction based on UN Comtrade data.

Consider the case of medicaments for retail—one of the top lead exports of South Africa. Using RCA and unit cost analysis, the study identifies printing machinery, parts, and accessories (used for printing labels on medicaments), as one of the key inputs which certain Southern African countries (Botswana, Mozambique, Namibia, and Zambia) can supply to South Africa. These Southern African economies have a higher bilateral RCA and lower import unit value than some of the current exporters of this product to South Africa. For instance, Zambia and Mozambique are more competitive than Lithuania and Ireland; Botswana is more competitive than Malaysia and Thailand; and Namibia is more competitive than Japan and China.

Based on the sum of current exports to South Africa from less-competitive exporters (in terms of both unit cost and comparative advantage), the study calculates the potential exports for each Southern African country. In the case of printing machinery, Zambia is currently exporting US $\$ 15,000$ to South Africa but has the potential to capture an additional market access of $\$ 35,000$ (the sum of total of exports of Lithuania and Ireland). Since its potential exports to South Africa are greater than what Zambia is currently exporting to the rest of the world, this indicates that Zambia may lack capacity to supply the product in greater volumes, suggesting a need for regional investments to boost productive and export capacity, including from South Africa. Since this product is currently being sourced from less-competitive suppliers, South Africa will also benefit from facilitating market access for Southern African countries.

Similarly, consider the case of telephones exported by South Africa. As per Table 2, both Zambia and Namibia can provide parts of telephone sets and other apparatus for transmissions (HS 851770) more competitively than some countries, such as Denmark, from which South Africa is currently importing.

An interesting point to note is that many of these competitor countries are currently supplying these intermediates to South Africa in the absence of a trade agreement. In this sense, Southern African countries have an additional advantage in the form of preferential market access through the SACU (Botswana, Namibia) or SADC (Mozambique, Zambia, Zimbabwe) trade agreements.

\subsection{New markets for South Africa in agricultural lead products}

Section 4.1 identified key industrial inputs that Southern African countries can supply to South Africa to link into its existing GVCs. SADC has earmarked agro-processing as one of the key regional priority value chains, whose global competitiveness needs to be boosted to spur industrial development in Southern Africa. The sector has immense potential to contribute to not only food security, large-scale employment, and income, but also industrial growth through global integration. The SADC region is endowed with an abundance of labour and raw materials, and therefore has a comparative advantage in production of agricultural commodities such as livestock, oilseeds, and sugarcane.

South Africa has the potential to become a growth pole for Southern Africa's agriculture sector. In order to identify potential RVCs in agriculture, we first identify new markets for South Africa's identified agricultural products. Increased demand for these products will enhance South Africa's capacity and need to develop RVCs in these products.

Of the top 20 agricultural lead products exported by South Africa, Table 3 identifies new markets for frozen hake, mixed juices, margarine, sunflower seed or safflower oil, solid sucrose, sweet 
biscuits, meat, and edible offal. These markets consist of the top ten importers of the product (in terms of value) which are importing the lead product from other countries, but not from South Africa, despite it being globally competitive in the product. In the case of cereals, while South Africa is not globally competitive, new markets are those that are importing from countries which are less competitive than South Africa in cereals. For example, Bangladesh is importing cereals from China, Japan, and Korea, which have a lower global RCA in cereals than South Africa.

Table 3: New export markets for South Africa's top agricultural lead products

\begin{tabular}{|c|c|c|c|}
\hline $\begin{array}{l}\text { HS lead } \\
\text { product }\end{array}$ & Product description & $\begin{array}{r}\text { Product-level } \\
\text { exports to the } \\
\text { world } \\
(1,000 \text { US } \$)\end{array}$ & New markets for export \\
\hline 30366 & Fish; frozen, hake (Merluccius spp., Urophycis spp.) & 40,520 & Serbia, Ukraine \\
\hline 200990 & $\begin{array}{l}\text { Juices; mixtures of fruits or vegetables, unfermented, } \\
\text { not containing added spirit, whether or not containing } \\
\text { added sugar }\end{array}$ & 83,009 & Russia \\
\hline 151710 & Margarine, excluding liquid margarine & 35,187 & $\begin{array}{l}\text { Germany, Finland, France, } \\
\text { Hungary, Italy, Saudi } \\
\text { Arabia, USA }\end{array}$ \\
\hline 151219 & $\begin{array}{l}\text { Vegetable oils; sunflower seed or safflower oil and their } \\
\text { fractions, other than crude, whether or not refined, but } \\
\text { not chemically modified }\end{array}$ & 72,287 & $\begin{array}{l}\text { Belgium, Belarus, } \\
\text { Germany Italy, Jordan, } \\
\text { Lebanon }\end{array}$ \\
\hline 170199 & $\begin{array}{l}\text { Sucrose; chemically pure, not containing added } \\
\text { flavouring or colouring matter, in solid form }\end{array}$ & 83,587 & $\begin{array}{l}\text { China, Sri Lanka, Saudi } \\
\text { Arabia, Sudan }\end{array}$ \\
\hline 190531 & Sweet biscuits & 39,371 & Italy, Saudi Arabi \\
\hline 20714 & $\begin{array}{l}\text { Meat and edible offal; of fowls of the species Gallus } \\
\text { domesticus, cuts and offal, frozen }\end{array}$ & 36,450 & $\begin{array}{l}\text { China, Germany, France, } \\
\text { UK, Hong Kong, Japan, } \\
\text { Saudi Arabia }\end{array}$ \\
\hline 100630 & $\begin{array}{l}\text { Cereals; rice, semi-milled or wholly milled, whether or } \\
\text { not polished or glazed }\end{array}$ & 44,304 & $\begin{array}{l}\text { Bangladesh, China, Côte } \\
\text { d'Ivoire, Japan, Malaysia, } \\
\text { Saudi Arabia }\end{array}$ \\
\hline
\end{tabular}

Source: Authors' construction based on UN Comtrade data.

Tracing the value chains in these agricultural lead products and carrying out analysis based on RCA reveals selected inputs in which Southern Africa can integrate regionally. Table 4 identifies six South African value chains (existing or new) that Southern African countries can link into: margarine; cosmetic and toilet preparations; solid sucrose; wine; mixed juices; and sweet biscuits. This can be done by increasing exports to South Africa in two key intermediate inputs-palm oil and cane sugar in solid form. While Botswana can provide palm oil to South Africa more competitively than the countries currently exporting to South Africa, cane sugar can be sourced from Zimbabwe, Zambia, and Botswana. 
Table 4: Linking Southern Africa into South Africa's existing and new agricultural value chains

\begin{tabular}{|c|c|c|c|c|}
\hline $\begin{array}{l}\text { Lead products } \\
\text { exported by } \\
\text { South Africa }\end{array}$ & $\begin{array}{l}\text { New markets } \\
\text { that South } \\
\text { Africa can } \\
\text { export to }\end{array}$ & $\begin{array}{l}\text { Intermediate inputs } \\
\text { that South Africa can } \\
\text { import from Southern } \\
\text { Africa }\end{array}$ & $\begin{array}{l}\text { Countries South Africa is } \\
\text { currently importing from }\end{array}$ & $\begin{array}{l}\text { Southern African } \\
\text { countries which } \\
\text { can provide input } \\
\text { more } \\
\text { competitively }\end{array}$ \\
\hline Margarine & $\begin{array}{l}\text { Germany, } \\
\text { Finland, France, } \\
\text { Hungary, Italy, } \\
\text { Saudi, USA }\end{array}$ & Vegetable oil; palm oil & $\begin{array}{l}\text { Portugal, Indonesia, } \\
\text { Malaysia, Sri Lanka, } \\
\text { France, Costa Rica, } \\
\text { Hungary, Cameroon, } \\
\text { Netherlands, Spain }\end{array}$ & Botswana \\
\hline $\begin{array}{l}\text { Cosmetic and } \\
\text { toilet } \\
\text { preparations }\end{array}$ & & Vegetable oil; palm oil & $\begin{array}{l}\text { Portugal, Indonesia, } \\
\text { Malaysia, Sri Lanka, } \\
\text { France, Costa Rica, } \\
\text { Hungary, Cameroon, } \\
\text { Netherlands, Spain }\end{array}$ & Botswana \\
\hline $\begin{array}{l}\text { Sucrose; } \\
\text { chemically } \\
\text { pure, solid }\end{array}$ & $\begin{array}{l}\text { China, Sri } \\
\text { Lanka, Saudi } \\
\text { Arabia, Sudan }\end{array}$ & $\begin{array}{l}\text { Sugars; cane sugar, } \\
\text { raw, in solid form, no } \\
\text { added flavouring }\end{array}$ & Germany, India & $\begin{array}{l}\text { Zimbabwe, } \\
\text { Zambia, } \\
\text { Botswana }\end{array}$ \\
\hline Wine & & $\begin{array}{l}\text { Sugars; cane sugar, } \\
\text { raw, in solid form, no } \\
\text { added flavouring }\end{array}$ & Germany, India & $\begin{array}{l}\text { Zimbabwe, } \\
\text { Zambia, } \\
\text { Botswana }\end{array}$ \\
\hline Mixed juices & Russia & $\begin{array}{l}\text { Sugars; cane sugar, } \\
\text { raw, in solid form, no } \\
\text { added flavouring }\end{array}$ & Germany, India & $\begin{array}{l}\text { Zimbabwe, } \\
\text { Zambia, } \\
\text { Botswana }\end{array}$ \\
\hline Sweet biscuits & $\begin{array}{l}\text { Italy, Saudi } \\
\text { Arabi }\end{array}$ & $\begin{array}{l}\text { Sugars; cane sugar, } \\
\text { raw, in solid form, no } \\
\text { added flavouring }\end{array}$ & Germany, India & $\begin{array}{l}\text { Zimbabwe, } \\
\text { Zambia, } \\
\text { Botswana }\end{array}$ \\
\hline
\end{tabular}

Source: Authors' construction based on UN Comtrade data.

\section{$5 \quad$ Conclusions and policy implications}

\subsection{Summary}

The study identifies lead products exported by South Africa, and then uses RCA and unit cost analysis to identify intermediate inputs in which Southern African countries have potential competitiveness to export to South Africa which is currently untapped. The study also identifies new markets for agricultural lead products exported by South Africa, which can open new opportunities for Southern Africa to supply agricultural intermediate inputs.

The products we have identified in this study for potential regional investments in Southern Africa are summarized in Table 5. 
Table 5: Identified products for potential regional investments and integration of Southern Africa into South Africa's GVCs

\begin{tabular}{|c|c|c|c|}
\hline Southern African country & $\begin{array}{l}\mathrm{HS} \\
\text { code }\end{array}$ & Intermediate input & $\begin{array}{l}\text { South African GVCs in which } \\
\text { intermediate product can be } \\
\text { used }\end{array}$ \\
\hline Zambia, Botswana, Mozambique, Namibia & 8443 & Printing machinery & Medicaments for retail \\
\hline Zambia, Botswana, Namibia, Mozambique & 8431 & $\begin{array}{l}\text { Parts of machinery } \\
\text { handling earth }\end{array}$ & $\begin{array}{l}\text { Vehicles for transport of } \\
\text { goods }\end{array}$ \\
\hline Zambia, Namibia & 8517 & $\begin{array}{l}\text { Telephone sets and } \\
\text { other apparatus; parts }\end{array}$ & Telephones \\
\hline Zambia, Botswana, Namibia & 8708 & $\begin{array}{l}\text { Vehicles; parts and } \\
\text { accessories }\end{array}$ & $\begin{array}{l}\text { Vehicles for transport of } \\
\text { goods }\end{array}$ \\
\hline Zambia, Botswana, Namibia & 8529 & $\begin{array}{l}\text { Reception and } \\
\text { transmission apparatus }\end{array}$ & $\begin{array}{l}\text { Telephones for cellular } \\
\text { networks or for other wireless } \\
\text { networks }\end{array}$ \\
\hline $\begin{array}{l}\text { Zambia, Botswana, Mozambique, Namibia, } \\
\text { Zimbabwe }\end{array}$ & 8481 & $\begin{array}{l}\text { Taps, valves, and other } \\
\text { appliances }\end{array}$ & Machinery for filtering gases \\
\hline Zambia, Botswana & 8803 & Parts of aircrafts & $\begin{array}{l}\text { Vehicles for transport of } \\
\text { goods }\end{array}$ \\
\hline $\begin{array}{l}\text { Zambia, Botswana, Mozambique, Namibia, } \\
\text { Zimbabwe }\end{array}$ & 8409 & Piston engines; parts & $\begin{array}{l}\text { Vehicles for transport of } \\
\text { goods }\end{array}$ \\
\hline Zambia, Botswana & 8421 & Centrifuges; parts & Machinery for filtering gases \\
\hline Namibia, Zimbabwe, Botswana & 4011 & Pneumatic rubber tyres & $\begin{array}{l}\text { Containers for carriage; } \\
\text { vehicles for transport of goods }\end{array}$ \\
\hline Mozambique, Namibia, Botswana, Zimbabwe & 8473 & $\begin{array}{l}\text { Parts and accessories of } \\
\text { automatic digital and } \\
\text { data processing units }\end{array}$ & $\begin{array}{l}\text { Telephones for cellular } \\
\text { networks or for other wireless } \\
\text { networks }\end{array}$ \\
\hline Botswana & 1511 & Vegetable oil; palm oil & $\begin{array}{l}\text { Margarine; cosmetic and toilet } \\
\text { preparations }\end{array}$ \\
\hline Zambia, Zimbabwe, Botswana & 1701 & Raw cane sugar & $\begin{array}{l}\text { Wine; mixed juices; sweet } \\
\text { biscuits }\end{array}$ \\
\hline
\end{tabular}

Source: Authors' construction based on UN Comtrade data.

\subsection{Conclusions}

Our identification of the top ten lead products exported by South Africa, and the associated intermediate inputs used in their production, corresponds fairly well with the priority sectors in the SADC Industrialization Strategy and Roadmap 2015-2063. The SADC-wide strategy emphasizes agro-processing, beneficiation, and manufacturing value added, targeting six main value chain clusters: agro-processing, mineral beneficiation, pharmaceuticals, other consumer goods (including leather, leather goods, and footwear; and clothing and textiles), capital goods (machinery and equipment, particularly for automobiles), and services. Among the top ten lead products exported by South Africa, the capital goods (e.g. vehicles), machinery (e.g. for filtering or purifying gases), pharmaceutical (e.g. medicaments), consumer goods (e.g. cosmetics and toiletries), and agroprocessing (e.g. wine, food preparations) sectors are all represented. This suggests that there is a strong policy foundation and an associated level of political commitment within the region to support value chain development in these areas. Moreover, the areas of alignment between the priority value chains in the SADC industrialization strategy and the lead products identified in this study provides a clear point of reference from which to prioritize regional interventions. Those lead products falling within these broader value chains already benefit from specific regional policy commitments.

Our analysis further finds that, of the Southern African countries, Botswana, Namibia, Zambia, and, to a lesser extent, Mozambique repeatedly emerge as potentially competitive suppliers of 
intermediate inputs in the production of the top lead products exported by South Africa. These countries appear to be best placed, at present, to link into RVCs led by South Africa, suggesting that there is a degree of concentration of capacity within the region. ${ }^{4}$ Attention will need to be directed to enhancing productivity and competitiveness in the countries that are not currently capable of serving as competitive suppliers of intermediates into value chains for South African lead products, to ensure that these countries are not excluded entirely from the development of RVCs in Southern Africa.

While we have identified specific Southern African countries with the potential-in terms of unit values and RCA at the product level-to supply intermediate inputs for use in the production of South Africa's top lead products, our analysis reveals little about why these countries remain poorly integrated. A possible reason includes a lack of capacity within these countries to produce the inputs: global exports of Southern African countries in the identified inputs are in most cases lower than the estimated potential exports in South Africa's markets. For example, we have identified parts and accessories of motor vehicles as key inputs that Botswana can supply to South Africa more cost-effectively than can South Africa's current import partners; however, very limited manufacturing activity has taken place in Botswana since the closure of the Hyundai vehicle assembly plant in the 2000s. More recently, some manufacturing operations have taken place, including the setting up of a wire harness manufacturer in Botswana contracted to supply German original equipment manufacturers in South Africa (Farole 2016). Focusing on how the supplier base for the South African automotive cluster can be further expanded into SACU markets may be important for boosting regional integration (Farole 2016). Investment is needed in areas where Southern African countries have competitiveness but lack supply capacity. Both regional and extraregional investments need to be attracted to these products in order to successfully create RVCs.

Another reason for the low level of integration of Southern African countries into South Africa's GVCs is the lack of harmonization in standards and an inability to meet the required quality. For instance, we identify vegetable oil and raw cane sugar as products that South Africa can source from some Southern African countries more cost-competitively than it can from its current import partners. However, to develop agro-processing RVCs in Southern Africa, asymmetries in both scale and standards will need to be addressed.

Future research could make an important contribution by unpacking why South African firms are not currently importing from suppliers of these products in other Southern African countries, and by developing a better understanding of existing supply capacity and constraints in these countries.

\subsection{Policy implications}

It is difficult to highlight targeted policy interventions without a detailed understanding of the specific capacity and competitiveness constraints affecting Southern African countries' ability to supply the identified intermediate products. These constraints are likely to be both product- and country-specific. It is therefore important to validate these potential RVCs, and the associated challenges, with industry consultations. Future research focused on identifying specific constraints at the product and country level could form the basis for targeted interventions to support the development of RVCs around each of the identified lead products exported by South Africa.

\footnotetext{
${ }^{4}$ Zambia and Mozambique are also among the countries identified by Balchin et al. (2016b) as good candidates for attracting foreign direct investment (FDI) into export-oriented manufacturing-Zambia was ranked first out of nine countries on the authors' Manufacturing FDI Potential Index.
} 
Nevertheless, at a more general level, the development of RVCs centred on these lead products can be supported by interventions focused in three main areas: (i) supplier capacity development; (ii) supporting regulations and policy frameworks; and (iii) complementary investments.

First, in the area of supplier capacity there may be scope and appetite for firms currently producing the lead products to initiate or support supplier development or business linkage programmes in Southern Africa, particularly given the evidence presented in this study that certain inputs could be sourced more competitively from selected Southern African countries. This could be facilitated by lead South African firms mentoring selected regional suppliers with direct support to meet product quality standards and volume requirements, with a view to developing supplier capacity gradually. More-general capacity-building efforts could concentrate on interventions to develop skills and well-trained human capital resources, or on the creation of specialist centres of excellence or knowledge and innovation hubs at the national and/or regional levels to support research and development and the enhancement of productive capacity.

Second, on the regulatory front, support could be directed to help firms in Southern African countries to meet and demonstrate compliance with the standards, quality assurance, and technical requirements necessary to supply inputs into the production of lead products in South Africa. Depending on the product or sector in question, this could be focused on strengthening national and regional standards, quality assurance, accreditation, or metrology infrastructure and systems. Developing common principles and harmonized regional standards frameworks can support these efforts, along with targeted capacity building for national standard bureaus and other agencies tasked with certification and accreditation. Focus should also be directed to improving sanitary and phytosanitary infrastructure and supporting institutions across Southern Africa.

Third, complementary investments can play a major role in the development of the identified RVCs. South Africa, as the headquarter economy in the region and exporter of an array of lead products linked into GVCs, is well placed to anchor the RVCs and channel extra- and intraregional productive investments into other Southern African countries. There are existing examples within the region where these types of investments have been successful, such as the case of South African investment in garment assembly operations in Lesotho (ODI 2009). In this role, South African firms producing the lead products can be local champions, leading a regional network of production and taking a central role in initiating technology and knowledge spillovers. This can support upgrading and productivity improvements in suppliers located in other Southern African countries.

South Africa and interested investors need to focus efforts in transferring skills and technology to the region to make labour more competitive, and in capacitating small and medium-sized enterprises to enter potential value chains. For products that are relatively more technologyintensive, such as machinery, electrical appliances, and motor vehicles, emphasis should be placed on developing design and engineering skills and capacity within regional suppliers, and on providing these firms with access to more-advanced technology. Additionally, South Africa can advise other SADC countries on how to develop their own components and assembly operations to be more competitive (Markowitz 2016). Deepening regional integration in services markets is also important, particularly in markets for business and professional services, which are key inputs to other sectors. Labour mobility within the region can be facilitated by expediting the implementation phases of the Protocol on Movements of Persons.

For such investments to be successful, however, an appropriate intra-regional investment framework is required that provides adequate incentives. Similarly, there is a need to support business environment improvements in individual Southern African countries; enhanced mobility of skills, capital, and firms across the region; convergence in intellectual property rights and 
competition policies; and harmonization of regulations and standards, including through regional policy frameworks.

At the same time, complementary support is required to ensure the efficient operation of RVCs and intra-regional trade. This should include the provision of enabling infrastructure (hard and soft) to address national and regional impediments to industrialization and regional integration in Southern Africa, with targeted emphasis on what is most needed to support intra-regional trade in the identified products (e.g. warehouse infrastructure for agro-processing). This sort of infrastructure provision could be supported regionally through a regional development fund or appropriate regional financing mechanisms.

\section{References}

AfDB (African Development Bank), OECD Development Centre, and United Nations Development Programme (2014). African Economic Outlook 2014: Global V alue Chains and Africa's Industrialisation. Abidjan: African Development Bank.

Allard, C., J.I.C. Kriljenko, W. Chen, J. Gonzalez-Garcia, E. Kitsios, and J. Treviño (2016). Trade Integration and Global Value Chains in Sub-Saharan Africa: In Pursuit of the Missing Link. Washington, DC: International Monetary Fund African Department.

Bagopi, E., E. Chokwe, P. Halse, J. Hausiku, M. Humavindu, W. Kalapula, and S. Roberts (2014). 'Competition Dynamics and Regional Trade Flows in the Poultry Sector: The Case of South Africa, Botswana, Namibia, and Zambia'. Paper presented at the Pre-ICN Conference, 22 April. Marrakech: International Competition Network.

Balassa, B (1965). 'Trade Liberalisation and "Revealed" Comparative Advantage'. The Manchester School, 33(2): 99-123.

Balchin, N., and L. Calabrese (2019, forthcoming). 'Comparative Country Study of the Development of Textile and Garment Sectors: Lessons for Tanzania'. London: ODI.

Balchin, N., L. Edwards, and A. Sundaram (2016a). 'Tariffs and the Border Effect: Evidence from the Southern African Development Community'. Unpublished mimeo.

Balchin, N., S. Gelb, J. Kennan, H. Martin, D.W. te Velde, and C. Williams (2016b). 'Developing Export-Based Manufacturing in Sub-Saharan Africa'. Supporting Economic Transformation Report, March. London: ODI.

Banga, K. (2017) 'Global Value Chains and Product Sophistication: An Empirical Investigation of Indian Firms'. CTEI Working Paper 2017-15. Geneva: Centre for Trade and Economic Integration (CTEI).

Banga, K., and D.W. te Velde (2018a). 'Digitalisation and the Future of Manufacturing in Africa'. Supporting Economic Transformation Briefing Paper, March. London: Overseas Development Institute.

Banga, K., and D.W. te Velde (2018b). 'How to Grow Manufacturing and Create Jobs in a Digital Economy: 10 Policy Priorities for Kenya'. Supporting Economic Transformation Briefing Paper, November. London: Overseas Development Institute.

Cai, J., and P. Leung (2008). 'Towards a More General Measure of Revealed Comparative Advantage Variation'. Applied Economics Letters, 15(9): 723-26.

Commonwealth Secretariat (2016). Boosting India's Exports by Linking LDCs into India's Potential Global V alue Chains: Trade Competitiveness Report. London: The Commonwealth. 
Commonwealth Secretariat (2017). Export Diversification of Jamaica: New Products and New Markets. London: The Commonwealth

Conde, C., P. Heinrings, and A. O'Sullivan (2015). 'Tapping the Potential of Global Value Chains for Africa'. In The Africa Competitiveness Report 2015. Geneva: World Economic Forum.

Das Nair, R., and S. Chisoro-Dube (2016). 'The Expansion of Regional Supermarket Chains and Implications for Local Suppliers: A Comparison of Findings from South Africa, Botswana, Zambia, and Zimbabwe'. WIDER Working Paper 2016/169. Helsinki: UNU-WIDER.

De Benedictis, L., and M. Tamberi (2004). 'Overall Specialization Empirics: Techniques and Applications'. Open Economies Review, 15(4): 323-46.

ECA-SA (Economic Commission for Africa, South Africa Office) (2018). 'The Private Sector and Regional Integration in Southern Africa: Accelerating Opportunities for Investment and Growth'. Background Paper Prepared for the Southern Africa Regional Integration Stakeholder Forum, Lilongwe, Malawi, 11-13 June.

Engel, J. (2016). SACU in Global Value Chains: Measuring GVC Integration, Position, and Performance of Botswana, Lesotho, Namibia, South Africa, and Swaziland. Washington, DC: World Bank.

Farole, T. (2016). Factory Southern Africa? S ACU in Global Value Chains: Summary Report. Washington, DC: World Bank.

Games, D. (2017). South Africa's Economic Engagement in Sub-Saharan Africa Drivers, Constraints and Future Prospects. London: Chatham House.

Godfrey, S. (2015) 'Global, Regional and Domestic Apparel Value Chains in Southern Africa: Social Upgrading for Some and Downgrading for Others'. Cambridge Journal of Regions, Economy and Society, 8(3): 491-504.

Grobbelaar, S.S., and I.A. Meyer (2017). 'The Dynamics of Regional Economic Integration: A System Dynamics Analysis of the Pathways to the Development of Value Chains in the Southern African Customs Union'. South African Journal of Industrial Engineering, 28(1): 73-89.

Hope, A. (2018). 'What is COMESA's Digital Free Trade Area and Should SADC Have One Too?' Tralac, 15 February. Available at: https://www.tralac.org/publications/article/12728-whatis-comesa-s-digital-free-trade-area-and-should-sadc-have-one-too.html (accessed 15 May 2019).

Kalenga, P. (2009). 'Implementation of the SADC Trade Protocol: Some Reflections'. Unpublished mimeo.

Keane, J. (2015a). 'Firms and Value Chains in Southern Africa'. ODI Working Paper, January. London: ODI.

Keane, J. (2015b). Regional Integration, Sustainable Development and Global Value Chains in Southern Africa. London: Commonwealth Secretariat.

Markowitz, C. (2016). 'Potential For Regional Value Chains in the Automotive Sector: Can SADC Learn from the Asean Experience?' Available at: https://www.africaportal.org/publications/potential-for-regional-value-chains-in-theautomotive-sector-can-sadc-learn-from-the-asean-experience (accessed 14 May 2019).

Ncube, P., S. Roberts, T. Zengeni, and P.C. Samboko (2017). 'Identifying Growth Opportunities in the Southern African Development Community through Regional Value Chains: The Case of the Animal Feed to Poultry Value Chain'. WIDER Working Paper 2017/4. Helsinki: UNUWIDER. 
ODI (2009). 'Aid for Trade in Lesotho: ComMark's Lesotho Textile and Apparel Sector Programme'. Case Study, June. London: ODI.

OECD (Organisation for Economic Co-operation and Development) (2015). 'Participation of Developing Countries in Global Value Chains: Implications for Trade and Trade-Related Policies'. OECD Trade Policy Paper 179. Paris: OECD Publishing.

SADC (2012). Regional Infrastrcuture Development Master Plan. Gaborone: SADC.

SADC (2014). SADC Industrial Development Policy Framework. Gaborone: SADC.

SADC (2015a). Revised Regional Indicative Strategic Development Plan (RISDP) 2015-2020. Gaborone: SADC.

SADC (2015b). SADC Industrialisation Strategy and Roadmap 2015-2063. Gaborone: SADC.

Tralac (2017). 'Intra-SADC Trade Remains Limited: How Can It Be Boosted?' Tralac, 2 August. Available at: https://www.tralac.org/discussions/article/11962-intra-sadc-traderemainslimited-how-can-it-be-boosted.html (accessed 15 May 2019).

UNCTAD (United Nations Conference on Trade and Development) (2013). World Investment Report: Global V alue Chains: Investment and Trade for Development. Geneva: UNCTAD. Available at: http://unctad.org/en/publicationslibrary/wir2013_en.pdf (accessed 2 May 2019).

UNCTAD (2018). Trade and Development Report 2018-Power, Platforms and The Free Trade Delusion. Geneva: UNCTAD.

UNECA (2015). 'Repositioning Africa in Global Value Chains and Facilitating Trade in Intermediates and Services'. In Economic Report on Africa 2015: Industrializing Through Trade. Addis Ababa: UNECA.

UNECA (2017). Accelerating Industrialization in Southern Africa through Beneficiation and Value Addition. Addis Ababa: UNECA.

Viviers, W., and P.D.F. Strydom (2015). 'Global Value Chains: A New Era For South Africa's Foreign Trade'. Africa Growth Agenda, 12(2): 4-7.

World Bank (2018). 'Aggregated LIP 2012-2018'. Available at: https://lpi.worldbank.org (accessed 17 June 2019). 


\section{Appendix}

Table A1: Identifying the top 20 imported inputs in South Africa's top ten lead products

\begin{tabular}{|c|c|c|c|}
\hline Lead product & $\begin{array}{l}\text { HS six- } \\
\text { digit } \\
\text { product }\end{array}$ & Intermediate input product description & $\begin{array}{r}\text { South Africa's } \\
\text { imports of } \\
\text { intermediates } \\
\text { (million US\$) }\end{array}$ \\
\hline Medicaments for retail & 844399 & Printing machinery; parts and accessories & 387.70 \\
\hline Food preparations; n.e.s. & 100199 & $\begin{array}{l}\text { Cereals; wheat and meslin, other than durum } \\
\text { wheat, other than seed }\end{array}$ & 367.76 \\
\hline $\begin{array}{l}\text { Machinery; for filtering or purifying } \\
\text { gases } \\
\text { Telephone for cellular networks or } \\
\text { for other wireless networks } \\
\text { Vehicles, for transport of goods }\end{array}$ & 843149 & $\begin{array}{l}\text { Machinery; parts of machines handling earth, } \\
\text { minerals, or ores and n.e.s. in heading no. } 8431\end{array}$ & 338.39 \\
\hline $\begin{array}{l}\text { Telephones for cellular networks } \\
\text { or for other wireless networks }\end{array}$ & 851770 & $\begin{array}{l}\text { Telephone sets and other apparatus for the } \\
\text { transmission or reception of voice, images, or } \\
\text { other data, via a wired or wireless network; } \\
\text { parts }\end{array}$ & 314.05 \\
\hline $\begin{array}{l}\text { Medicaments } \\
\text { Cosmetic and toilet preparations }\end{array}$ & 151190 & $\begin{array}{l}\text { Vegetable oils; palm oil and its fractions, other } \\
\text { than crude, whether or not refined, but not } \\
\text { chemically modified }\end{array}$ & 287.66 \\
\hline Vehicles for transport of goods & 870829 & $\begin{array}{l}\text { Vehicles; parts and accessories, of bodies, } \\
\text { other than safety seat belts }\end{array}$ & 279.43 \\
\hline $\begin{array}{l}\text { Telephones for cellular networks } \\
\text { or for other wireless networks }\end{array}$ & 852990 & $\begin{array}{l}\text { Reception and transmission apparatus; for use } \\
\text { with the apparatus of heading no. } 8525 \text { to } 8528 \text {, } \\
\text { excluding aerials and aerial reflectors }\end{array}$ & 271.23 \\
\hline $\begin{array}{l}\text { Vehicles for transport of goods } \\
\text { Containers for carriage }\end{array}$ & 870899 & $\begin{array}{l}\text { Vehicles; parts and accessories, n.e.s. in } \\
\text { heading no. } 8708\end{array}$ & 260.28 \\
\hline $\begin{array}{l}\text { Machinery for filtering or purifying } \\
\text { gases }\end{array}$ & 848180 & $\begin{array}{l}\text { Taps, cocks, valves, and similar appliances; for } \\
\text { pipes, boiler shells, tanks, vats or the like, } \\
\text { including thermostatically controlled valves }\end{array}$ & 243.01 \\
\hline $\begin{array}{l}\text { Vehicles for transport of goods } \\
\text { Containers for carriage }\end{array}$ & 880330 & $\begin{array}{l}\text { Aircraft and spacecraft; parts of aeroplanes or } \\
\text { helicopters n.e.c. in heading no. } 8803\end{array}$ & 228.52 \\
\hline Containers for carriage & 401120 & $\begin{array}{l}\text { New pneumatic tyres, of rubber, of a kind used } \\
\text { on buses or lorries }\end{array}$ & 217.23 \\
\hline $\begin{array}{l}\text { Telephones for cellular networks } \\
\text { or for other wireless networks }\end{array}$ & 847330 & $\begin{array}{l}\text { Machines; parts and accessories of automatic } \\
\text { data processing, magnetic or optical readers, } \\
\text { digital processing units }\end{array}$ & 199.35 \\
\hline $\begin{array}{l}\text { Telephones for cellular networks } \\
\text { or for other wireless networks }\end{array}$ & 854140 & $\begin{array}{l}\text { Electrical apparatus; photosensitive } \\
\text { semiconductor devices; (LED) }\end{array}$ & 194.78 \\
\hline Vehicles for transport of goods & 401110 & $\begin{array}{l}\text { New pneumatic tyres, of rubber, of a kind used } \\
\text { on motor cars }\end{array}$ & 181.2473 \\
\hline Vehicles for transport of goods & 870830 & $\begin{array}{l}\text { Parts and accessories of the motor vehicles of } \\
\text { headings; brakes, and servo-brakes; parts } \\
\text { thereof }\end{array}$ & 173.31 \\
\hline $\begin{array}{l}\text { Vehicles for transport of goods } \\
\text { Containers for carriage }\end{array}$ & 854430 & $\begin{array}{l}\text { Ignition wiring sets and other wiring sets used in } \\
\text { vehicles, aircraft, or ships }\end{array}$ & 149.53 \\
\hline $\begin{array}{l}\text { Telephones for cellular networks } \\
\text { or for other wireless networks } \\
\text { Machinery; for filtering or purifying } \\
\text { gases }\end{array}$ & 853710 & $\begin{array}{l}\text { Boards, panels, consoles, desks, cabinets, and } \\
\text { other bases, for electric control or the } \\
\text { distribution of electricity }\end{array}$ & 137.20 \\
\hline $\begin{array}{l}\text { Wine, in containers, more or less } \\
\text { than } 2 \text { litres }\end{array}$ & 170113 & $\begin{array}{l}\text { Sugars; cane sugar, raw, in solid form, not } \\
\text { containing added flavouring }\end{array}$ & 133.81 \\
\hline
\end{tabular}


Vehicles for transport of goods

Containers for carriage

840999 Engines; parts for internal combustion piston

engines (excluding spark-ignition)

Machinery for filtering or purifying 842199 Machinery; centrifuges, parts for filtering or gases purifying liquids or gases
Note: n.e.s. $=$ not elsewhere classified

Source: Authors' construction based on UN Comtrade (BEC data). 